\title{
CARDIAC EFFECTS OF SELF-TAMING OF SUCCINYLCHOLINE AND REPEATED SUCCINYLCHOLINE ADMINISTRATION
}

\author{
D.A. Magee, P.T. Sweet and A.J.C. Holland
}

\begin{abstract}
Pretreatment with small (10 mg) doses of succinylcholine ("self-taming") decreases the incidence of muscle fasciculations following succinylcholine administration and may decrease the incidence of other unwanted effects. This study was designed to assess the cardiac effects of such self-taming and to assess the degree of protection afforded against bradydysrhythmias following subsequent succinylcholine administration. Sixty patients were studied and allocated randomly to three groups of twenty. Each group was assigned a different form of pretreatment. Patients in group I received $10 \mathrm{mg}$ of succinylcholine immediately after induction. Patients in group II were treated with d-tubocurarine 0.04 $\mathrm{mg} \cdot \mathrm{kg}^{-1}$ three minutes before induction. Patients in group III received no pretreatment. All patients were induced with thiopentone $4 \mathrm{mg} \cdot \mathrm{kg}^{-1}$ followed by succinylcholine $1 \mathrm{mg} \cdot \mathrm{kg}^{-1}$ 45 seconds later. A second dose of succinylcholine $1 \mathrm{mg} \cdot \mathrm{kg}^{-1}$ was administered to the patients in the two pretreatment groups between four and five minutes after the first dose of succinylcholine. Following both the first and second doses of succinylcholine patients in the self-taming group showed a significantly greater incidence of bradydysrhythmias when compared to the other two groups. It is concluded that the use of a self-taming technique is potentially hazardous, and that it does not confer protection against repeated succinylcholine administration.
\end{abstract}

KEY WORDS: NEUROMUSCULAR RELAXANTS, succinylcholine, d-tubocurarine; COMPLICATIONS, bradydysrhythmia.

MANY OF THE unwanted effects of succinylcholine administration can be prevented by the prior administration of small, sub-paralytic doses of non-depolarizing neuromuscular blocking drugs. ${ }^{1}$ Such pretreatment is associated with diminished intensity and delayed onset of neuromuscular block. ${ }^{2}$ To overcome these objections Baraka (1977) introduced the concept of pretreatment with small $(10 \mathrm{mg})$ doses of succinylcholine. ${ }^{3}$ This technique was not assaciated with paradoxical antagonism, and the resulting neuromuscular block was normal in timing and intensity.

The purpose of our study was to investigate the cardiac effects of such "self-taming" and to ascertain if such pretreatment conferred any protection against bradydysrhythmias consequent upon subsequent doses of succinylcholine.

D.A. Magee, M.B., B.Ch., F.F.A.R.C.S.I., Clinical Fellow; P.T. Sweet, M.B., Bs., (Lond.) F.F.A.R.C.S., Clinical Fellow; Á.J.C. Holland, M.B., B.S., F.F.A.R.C.S., D.C.H., Associate Professor; Department of Anaesthesia, The Montreal General Hospital and McGill University.

For reprints and correspondence: Dr. D.A. Magee, Senior Registrar in Anaesthesia, Regional Hospital, Galway, County Galway, Ireland.

\section{Methods}

Sixty patients of ASA class I presenting for routine gynaecological operations were studied. All patients were visited preoperatively by one of us, and informed consent was obtained. The procedure was approved by the hospital ethical committee. Premedication consisted of an intramuscular injection of meperidine $50 \mathrm{mg}$ and promethazine $25 \mathrm{mg}$ one hour before operation. The patients were randomly allocated to three groups, with twenty patients in each group.

Patients in the first group were pretreated with d-tubocurarine $0.04 \mathrm{mg} \cdot \mathrm{kg}^{-1}$ three minutes before induction of anaesthesia. ' Patients in the second group received a self-taming dose of succinylcholine $(10 \mathrm{mg})^{3}$ immediately following induction. Patients in the third (control) group received no pretreatment (Figure 1).

Anaesthesia was induced with thiopentone 4 $\mathrm{mg} \cdot \mathrm{kg}^{-1}$ and maintained with nitrous oxide 70 per cent with oxygen. All patients received a full paralyzing dose of succinylcholine $1 \mathrm{mg} \cdot \mathrm{kg}^{-1}$ 45 seconds after induction (succinylcholine I). ${ }^{3}$ Tracheal intubation was not attempted nor did the operation commence during the study

Can. Anaesth. Soc. J., vol. 29, no, 6, November 1982 


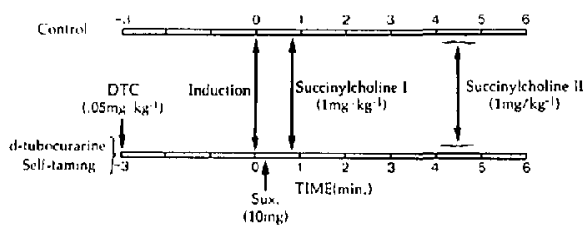

FIGURE 1 Time sequence of anaesthesia and administration of drugs. $\_$indicates range af times.

period. Neuromuscular blockade was monitored with a peripheral nerve stimulator, using single twitches at 10 second intervals, and when neuromuscular transmission returned to pre-succinylcholine levels a second dose of succinylcholine $1 \mathrm{mg} \cdot \mathrm{kg}^{-1}$ was administered to patients in the two pretreatment groups (succinylcholine II). The time interval between succinylcholine doses was four to five minutes in all cases. It was felt to be ethically unjustifiable to repeat the succinylcholine dose in the control group who were not pretreated, in view of the severe bradydysrhythmias which have been demonstrated to occur. ${ }^{4}$

Throughout the study period the electrocardiogram was monitored using a Tektronix model 414 monitor with a continuous readout, which was analyzed postoperatively by one of the authors who was not involved with the anaesthetic and who did not know the anaesthetic technique used.

All patients had normal preoperative serum potassium levels. An arterial blood sample was taken immediately after the initial dose of succinylcholine and again after the subsequent dose, and $\mathrm{Paco}_{2}$ was measured with a Corning model 165 blood gas analyzer. In order to exclude changes in cardiac rate and rhythm caused by gross alterations in $\mathrm{Paco}_{2}$ it was decided that a range of $\mathrm{PacO}_{2}$ between 3.3 and 6.7 $\mathrm{kPa}\left(25\right.$ and $50 \mathrm{mmHg}$ ) would be acceptable, ${ }^{5}$ and all patients fell within these limits.

The data were analyzed by student's $t$ test and $x^{2}$ test where appropriate.

\section{RESULtS}

The mean heart rate throughout the study is shown in figure 2. There was no significant difference between the mean heart rate of the three groups before pretreatment (student's $t$ test).

Figure 3 shows the maximum changes in heart rate and also the changes in rhythm from immediately after induction to one minute after

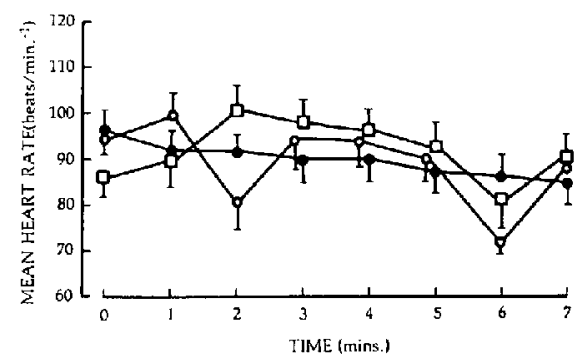

FIGURE 2 Mean heart rates \pm S.E.M. during the observation period. $\mathrm{O}-\mathrm{O}$ : self-taming. control group. $\square-\square$ : d-tubocurarine pretreatment.

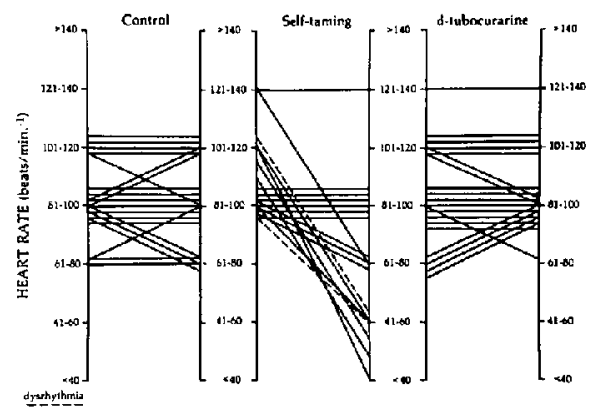

FIGURE 3 Maximum changes in heart rate and rhythm from induction to one minute after succinylcholine I.

administration of succinylcholine I. Eleven patients in the self-taming group showed cardiac abnormalities during this period. Nine patients showed a fall of 25 per cent more from their minimum pre-succinylcholine I level and one of these patients also developed bigeminal rhythm. Two further patients developed nodal rhythm without cardiac slowing. In comparison, no patients in either the control or d-tubocurarine pretreated groups developed either bradycardia or dysrhythmia. These changes were significant at the level $P<0.01$ (student's $t$ test and $\chi^{2}$ test).

Figure 4 shows the maximum changes in heart rate and rhythm from one minute before administration of succinylcholine II to one minute after. In the self-taming group 10 patients showed a slowing in heart rate of 50 per cent or more from the slowest pre-succinylcholine II rate, eight of whom also had dysrhythmias. In the d-tubocurarine pretreatment group two patients developed bradycardia and one patient showed nodal rhythm. No patients in the control group showed cardiac abnormalities. These dif- 


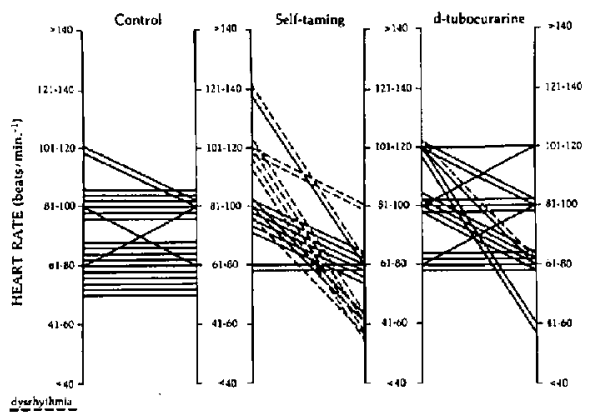

FIGURE 4 Maximum changes in heart rate and rhythm after succinylcholine II. Changes in control group over the same period.

ferences were significant at $\mathrm{P}<0.05$ (student's $t$ test and $x^{2}$ test).

\section{Discussion}

Self-taming was observed by Baraka (1977) to diminish succinylcholine-induced muscle fasciculations. Subsequent work has shown that such pretreatment does not prevent postoperative myalgia, ${ }^{6}$ but may diminish the succinylcholine-induced increase in intraocular pressure, ${ }^{7}$ though even that is debatable. ${ }^{8}$ The increases in creatine phosphokinase and serum potassium provoked by succinylcholine may also be ameliorated. ${ }^{9}$ No previous investigators who have studied self-taming have reported the occurrence of bradydysrhythmias during their investigations. Single doses of succinylcholine in children may cause rhythm disturbances. ${ }^{10} \mathrm{In}$ adults, repeated succinylcholine administration, when the second injection of succinylcholine occurs within a critical period of the first injection, may cause bradydysrhythmias. ${ }^{4}$ The onset of this critical period occurs when the time interval between repeated succinylcholine administrations is greater than three minutes. ${ }^{11}$ Thiopentone induction ${ }^{11,12}$ and d-tubocurarine pretreatment ${ }^{13}$ exert a protective effect against such dysrhythmias.

The precise pathway by which succinylcholine exerts its bradydysthythmic effect on the heart remains to be elucidated, despite numerous investigations. ${ }^{13}$ D-tubocurarine may minimize succinylcholine-induced bradydysthythmias by preventing stimulation of the receptor site by succinylcholine, ${ }^{13}$ perhaps by diminishing receptor uptake of succinylcholine which as been shown to occur at the neuromuscular junction. ${ }^{14}$
Baraka has suggested that the taming effects of small doses of succinylcholine may be attributed to neuromuscular accommodation and/or desensitization. ${ }^{3}$ The subsequent full dose of succinylcholine may then produce blockade without actual electrical excitation of the neuromuscular junction. A similar mode of action might reasonably be expected at the cardiac receptor site when a self-taming technique is used. Our studies have shown, however, that marked changes in cardiac rate and rhythm occur not only after a very small (10 mg) sensitizing dose of succinylcholine, but that an interval between doses as short as forty-five seconds is in itself sufficient to produce marked changes in cardiac rate and rhythm. It is also clear from this study that self-taming does not protect the heart against the dysrhythmias caused by subsequent doses of succinylcholine.

None of the patients in our series were given anticholinergic drugs either as a part of their premedication or at induction. Conversely in other studies using a self-taming technique atropine was given either with the premedication $^{3,4,7.8}$ or intravenously at induction. ${ }^{6,15}$ Atropine has been shown not to protect against serious bradycardia when given in doses of 0.01 $\mathrm{mg} \cdot \mathrm{kg}^{-1}$ either as part of the premedication or intravenously at induction, ${ }^{16}$ nor does atropine administration affect the protection afforded by pretreatment with gallamine. ${ }^{5}$ While this evidence makes the omission of atropine in our series less likely to be the cause of the high incidence of cardiac effects, such a possibility cannot be excluded.

From this small study we conclude that the use of self-taming is associated with an unacceptably high incidence of bradydysrhythmias in healthy young patients and does not confer protection against subsequent succinylcholine administration. If this technique is used, cardiac monitoring is essential and caution should be observed if subsequent doses of succinylcholine are to be administered.

\section{REFERENCES}

1. Stoelting, R.K. \& Peterson, C. Adverse effects of increased succinylcholine dose following d-tubocurarine pretreatment. Anesth. Analg. (Cleve). 54: 282 (1975).

2. Paula, A.L., Reynolds, R.C. \& Strobel, G.E. Inhibition of suxamethonium relaxation by tubocurarine and gallamine pretreatment during induction of anaesthesia in man. Br. J. Anaesth. 47: 1067 (1975). 
3. Baraka, A. Self-taming of succinylcholineinduced fasciculations. Anesthesiology. 46: 292 (1977).

4. LIST, W.F.M. Succinylcholine-induced cardiac arrhythmias. Anesth. Analg. (Cleve). 50: 361 (1971).

5. Viby-Mogensen, J., Wisborg, K. \& SorenSEN, O. Cardiac effects of atropine and gallamine in patients receiving suxamethonium. $\mathrm{Br}$. $\mathrm{J}$. Anaesth. 52: 1137 (1980).

6. Brodsky, J.B. \& BROCK-UTNE, J.G. Does "self-taming" with succinylcholine prevent postoperative myalgia? Anesthesiology. 50: 265 (1979).

7. Verma R.S. "Self-taming" of succinylcholineinduced fasciculations and intraocular pressure. Anesthesiology. 50: 245 (1979)

8. Meyers, E.F. Singer, P. \& OTto A. A controlled study of the effect of succinylcholine self-taming on intraocular pressure. Anesthesiology. 53: 72 (1980).

9. Charak, D.S. \& Dhar, C.L. Suxamethonium induced changes in serum creatine phosphokinase. Br. J. Anaesth. 53: 955 (1981).

10. LEIGH, M.D., MCCOY, D.D., BELTON, M.K. \& LEWIS, J.B. Bradycardia following intravenous administration of succinylcholine to infants and children. Anesthesiology. 18: 698 (1957).

11. Schoenstadt, D. A. \& Whitcher, C.E. Observations on the mechanism of succinylcholineinduced cardiac arrhythmias. Anesthesiology. 24: 358 (1963)

12. ANDERSEN, J.R. \& Eikard, B. Amhythmias during halothane anaesthesia III. The influence of the barbiturates. ACTA Anaesthesiol. Scand. 22: 430 (1978).

13. Karhunen, U., Heinonen, J. \& Tammisto, T. The effect of tubocurarine and alcuronium on suxamethonium induced changes in cardiac rate and thythm. ACTA Anaesthesiol. Scand. 16: 3 (1972).

14. TAYLOR, D. The mechanism of action of muscle relaxants and their antagonists. Anesthesiology. 20: 439 (1959)

15. Silar, J.N., CoOK, F.J. \& Ricca, J. Does "Self-Taming" Decrease Post-operative Myalgia in Outpatients? Anesthesiology. 52: 98 (1980)

16. Viby-Mogensen, J., Wisborg, K., GabrielSEN, J. \& SPOTOFT, H. Halothane anaesthesia and suxamethonium I: The significance of preoperative atropine administration. ACTA Anaesthesiol. Scand. 20: 129 (1976).

\section{RÉSUMÉ}

L'Administration d'une petite dose $(10 \mathrm{mg})$ de succinylcholine précédant la dose dépolarisante de cet agent diminue l'incidence des fasciculations musculaires couramment observées avec le succinylcholine et pourrait également diminuer l'incidence d'autres effets indésirables. L'objet de ce travail était de vérifier si l'administration préalable d'une petite dose de succinylcholine diminuait aussi l'incidence des bradyarythmies fréquemment associées à l'usage de ce dépolarisant.

Soixante patients ont été étudiés. Ils ont été assignés au hasard à l'une de trois groupes. Ceux du groupe I ont reçu $10 \mathrm{mg}$ de succinylcholine immédiatement après l'induction de l'anesthésie, ceux du groupe II, $0.04 \mathrm{mg} \cdot \mathrm{kg}^{-1}$ de d-tubocurarine trois minutes avant l'induction, alors que les patients du groupe III n'ont reçu aucun pré-traitement. L'induction de l'anesthésie de tous les patients a été effectuée au thiopental $4 \mathrm{mg} \cdot \mathrm{kg}^{-1}$ suivi, après intervalle de 45 secondes, d'une dose de succinylcholine $1 \mathrm{mg} \cdot \mathrm{kg}^{-1}$. Une dose semblable de succinylcholine était répétée chez les patients des deux premiers groupes, quatre à cinq minutes après la première dose de cet agent. Les patients ayant reçu la petite dose (10 mg) de succinylcholine avant la dose dépolarisante (premier groupe) ont présenté une incidence significativement plus élevée de bradyarythmies que ceux des deux derniers groupes.

Nous concluons que l'administration d'une petite dose de succinylcholine avant la dose dépolorisante peut être dangeureuse, et ne protège pas contre les arythmies associées avec les doses subséquentes de cet agent. 